\title{
THE IMPLIED TERM OF TRUST AND CONFIDENCE: THE CHANGE IN APPROACH OF THE COURT OF APPEAL TO THE REQUIREMENT TO PAY REDUNDANCY COMPENSATION
}

\author{
Ross Nelson*
}

This article examines the changing views of the Court of Appeal to payment of redundancy compensation where a contract of employment is silent. The author contrasts the leading cases, particularly Brighouse and Aoraki, and examines their differing approaches to issues such as the intention and interpretation of the Employment Contracts Act 1991, the extent of the implied term of mutual trust and confidence, and the perceived need for certainty in the law. The article concludes that the outcome is at least partly a result of changing judicial politics, and that perceptions of the correctness or otherwise of the current law will largely depend on readers views of ideology and politics.

\section{INTRODUCTION}

"Brighouse is overturned", a short phrase in the opening paragraphs of the majority judgment in Aoraki Corporation v McGavin, ${ }^{1}$ the strength of which left little doubt as to the result of the case before the Court. Once again, redundancy law and procedural fairness were in the limelight of New Zealand employment law. More importantly, once again, there was a change in the approach of the Court in this area.

The law in relation to redundancy compensation in New Zealand has been a highly controversial one. Employment law is a very political area, and this, coupled with the fundamental importance of the issue the Courts are dealing with, has meant that developments in the area are closely followed and scrutinised.

* This paper was submitted in fulfilment of the LLB (Hons) requirements at Victoria University in 1999.

1 Aoraki Corporation v McGavin [1998] 1 ERNZ 601 (CA) [Aoraki v McGavin]. 
The Aoraki decision is a particularly interesting one. In it the Court of Appeal reconsidered an area of the law that had already been addressed less than four years earlier by it in Brighouse Ltd $v$ Bilderbeck. ${ }^{2}$ In that case the Court held that procedural fairness may require the payment of redundancy compensation, even in the absence of an express term requiring it in a contract. This decision was one of the most controversial in employment law in recent times and was subject to a great deal of criticism. The common theme of this criticism was that in extending the term of mutual trust and confidence to require such a payment the Court had gone too far in implying a substantive obligation into employment contracts. It is this aspect of the Brighouse decision that the Court of Appeal in Aoraki has now overturned.

This paper will consider the judgments of the Court of Appeal in Aoraki Corporation Ltd $v$ McGavin and its earlier decision in Brighouse $v$ Bilderbeck Ltd. These cases involved a consideration of the same legal issue in similar factual contexts. In each instance, the Court of Appeal recognised that there is an implied term of mutual trust and confidence in employment contracts. In both cases the Court applied the law under the Employment Contracts Act 1991, and in doing so each considered the purpose and effect of that legislation. However, despite these similarities, the decisions reached by the Courts in each instance were completely at odds with each other.

This paper will focus on factors apparent in the judgments of the Court which appear to be influential ones in its decision to overrule Brighouse. Often the Courts in each case have taken divergent views as to the proper approach to the law. These are areas subject to a great deal of debate. This paper will provide the reader with a degree of background to each side of the relevant debates in order to allow a better understanding of how the two Courts could reach outcomes so diametrically opposed. It will become apparent that often there are valid justifications for the differing approaches taken in both decisions. The approach one considers to be "correct" hinges largely on one's ideological perspective in relation to the Employment Contracts Act, and the nature of the employment relationship and contracts.

It has been said that redundancy is: ${ }^{3}$

An oscillating battle between, on the one hand, a recognition of the managerial prerogative of the employer to control their business and of the need for economic efficiency and, on the other, the employee's claim for security in their job and the more humanitarian need to protect the rights of the vulnerable, and to provide a remedy when those rights have been infringed.

2 Brighouse Ltd v Bilderbeck [1994] 2 ERNZ 243 (CA).

3 Judith Ferguson "Personal Grievances Arising from Redundancy: Life after Hale and the Employment Contracts Act 1991" (1992) 17(3) NZJIR 371. 
The changing nature of the law in this area is, in part, an illustration of this battle. What will become apparent is that essentially the difference in the approaches of the Court comes down to differing perceptions of the importance and weight that should be accorded to each of these considerations. In a sense therefore, the change in the law is a manifestation of judicial policy making and the differing stances of the Court of Appeal in relation to this over recent times.

\section{THE IMPLIED TERM OF MUTUAL TRUST AND CONFIDENCE}

The implied term of mutual trust and confidence is of central importance to the decisions in both Brighouse and Aoraki. It was from this term that the Court in Brighouse developed the requirement to pay redundancy compensation in the absence of an express contractual requirement to do so.

The implied term of trust and confidence is an undefined term central to modern employment law. Amongst other things it underlies the concept of procedural fairness in dismissals. Accordingly, the extent to which the Courts are prepared to read the term into contracts impacts directly on the requirements of procedural fairness under the personal grievance jurisdiction. Although the term was accepted by both the Court in Brighouse and the Court in Aoraki to be a term in employment contracts, they differed in the degree to which they were willing to extend it.

\section{A Background of the Implied Term}

The implied term of mutual trust and confidence has its origins in the English courts where it emerged as a broad duty in the 1970s. ${ }^{4}$ New Zealand has followed this approach and it is now clear law that mutual obligations of trust and confidence are implied terms in all employment contracts. ${ }^{5}$

In New Zealand the courts have followed Woods v W M Car Services (Peterborough) Ltd ${ }^{6}$ which held that the term meant that "the employer will not, without reasonable and proper cause, conduct themselves in a manner calculated or likely to destroy or seriously damage the relationship of confidence and trust between employer and employee." 7

4 Roger W Rideout and Jacqueline Dyson Rideout's Principles of Labour Law (4 ed, Sweet \& Maxwell, London, 1983) 69.

5 Unkovich v Air New Zealand Ltd [1993] 1 ERNZ 526, 589 (EC) per Colgan J.

6 Woods $v$ W M Car Services (Peterborough) Ltd [1981] ICR 666. This was appealed in Woods $v$ W M Car Services (Peterborough) Ltd [1982] ICR 693 (CA), where the English Court of Appeal cast no doubt on this principle.

7 Auckland Shop Employees Union v Woolworths NZ Ltd [1985] 2 NZLR 372, 375 (CA) per Cooke P for the Court. 
However "[t]he law in this area by necessity remains more of an art than a science", 8 and hence the term remains largely undefined and possibly indefinable. ${ }^{9}$ This approach gives the Courts flexibility in their application of the term and allows them to reflect and validate the community's current notions of morality in relation to maintaining the balance between conflicting rights and freedoms. ${ }^{10}$

While the imposition of this implied term is an area of controversy in itself, it was in fact the issue of what obligations and duties the term imposes which split the Court in Brighouse, ${ }^{11}$ and on which the Court in Aoraki has now changed tack.

\section{REDUNDANCY AS A DISMISSAL - SECTION 27}

\section{A The Definition of Redundancy}

The Employment Contracts Act makes virtually no reference to redundancy ${ }^{12}$ and it is not a concept that is defined by statute in New Zealand. The Labour Relations Act 1987 defined redundancy as a situation where: ${ }^{13}$

A worker's employment is terminated by the employer, the termination being attributable, wholly or mainly, to the fact that the position filled by that worker is, or will become, superfluous to the needs of the employer.

In G N Hale \& Son Ltd $v$ Wellington, etc, Caretakers, etc, IUW, Cooke P referred to this definition and found that it accorded with common usage. ${ }^{14}$ So while it remains true that employers and employees are free to define redundancy themselves, as they have always been free to do, ${ }^{15}$ the section 184(5) definition remains an applicable one in the absence of an alternative definition. ${ }^{16}$

8 Walden v Barrance [1996] 2 ERNZ 598, 615 (EC) per Goddard CJ.

9 Robyn Mackay (ed) Butterworths Employment Law Guide (4 ed, Butterworths, Wellington, 1998) 985 [Employment Law Guide]. See also Unkovich v Air New Zealand Ltd above n 5, 589 per Colgan J.

10 Walden v Barrance, above n 8, 615.

11 Brighouse v Bilderbeck, above n 2, 266 per Richardson J dissenting.

12 JP Horn (ed) Brooker's Employment Contracts (Brooker's, Wellington, 1991) para EC27.34.1.

13 Labour Relations Act 1987, s184(5), repealed by the Employment Contracts Act 1991.

14 G N Hale \& Son Ltd v Wellington, etc, Caretakers, etc, IUW [1991] 1 NZLR 151, 155 (CA) per Cooke P [Hale $v$ Wellington, Caretakers, IUW].

15 Ferguson, above n 3, 374.

16 Robyn Mackay (ed) Mazengarb's Employment Law (Butterworths, Wellington, 1994) para 1202 (updated Jan 1997) [Mazengarb's Employment Law]. 


\section{B Unjustified Dismissal}

Section 27(a) provides that an employee may have a personal grievance against their employer where they have been unjustifiably dismissed. Although used in the Industrial Relations Act 1973 and the Labour Relations Act 1987, neither of the terms "unjustifiable" or "dismissed" have been defined by statute. This has meant the courts have largely been left to formulate the law in this area.

\section{Redundancy as a dismissal}

The judgment of Williamson J in Wellington Clerical etc IUW $v$ Greenwich ${ }^{17}$ has been described as the "most extensive and literary" discussion of the meaning of "dismissal" in New Zealand. ${ }^{18}$ In it, he was conscious to remove the negative connotations associated with the term and therefore adopted the broad definition of "termination of employment at the initiative of the employer."19 In Principal of Auckland College of Education $v$ Hagg the majority of the Court of Appeal considered the definition of "dismiss" and while they did not refer to the Greenwich definition, their formulation of a definition seems to accord with it. $^{20}$ Redundancy situations fit within this definition of dismissal, and therefore the Employment Contracts Act 1991 imposes certain obligations and duties on the employer.

\section{Meaning of "unjustifiable"}

The Court of Appeal recently made the following comments on the meaning of "unjustifiable":21

The statutory concept is concerned with both the reason for the dismissal and the manner in which it is arrived at and carried out: with substantive justification and with procedural fairness. The nature and circumstances of the particular case must be of paramount importance and this Court has deliberately avoided the temptation to formulate detailed rules by which the justifiability or unjustifiability of dismissals is to be determined.

17 Wellington Clerical etc IUWv Greenwich [1983] ACJ 965.

18 Employment Law Guide, above n 9, 249.

19 Wellington Clerical etc IUW v Greenwich, above n 17, 974. This definition is taken from ILO Convention 158 "Termination of Employment", which is not ratified by New Zealand. See Employment Law Guide, above n 9, 215-217.

20 Principal of Auckland College of Education v Hagg [1997] ERNZ 116, 124 (CA) per Richardson P [Auckland College of Education v Hagg].

21 Auckland College of Education v Hagg above n 20, 124-125 per Richardson P. Interestingly, this statement is exactly the same as Richardson J's (as he then was) comments on "unjustifiable" in Hale v Wellington, Caretakers, IUW, above n 14, 157 per Richardson J. 
Two key points are illustrated in this statement. The first is that "unjustifiable" is not a concept that the Courts have attempted to define. It is "directed at notions of moral justice" and is to be determined by considering and balancing the interests of the employee and the employer. ${ }^{22}$

Secondly, there are two limbs to unjustifiability: substantive justification and procedural fairness.

\section{(a) Substantive justification}

In the case of redundancy, it must be shown that the decision was justified on commercial grounds in order for it to be substantively justified. The decision of the Court of Appeal in G N Hale and Son Ltd $v$ Wellington, etc, Caretakers, etc IUW ${ }^{23}$ is significant in this area. In it the Court found that it could look at the genuineness of the employer's commercial reasons for redundancy, however, contrary to the law previously, the adequacy of those reasons was a matter for the employer's judgement and that it was not the place of the Court to substitute their judgement for that of the employer. ${ }^{24}$

\section{(b) Procedural fairness}

Even where a dismissal is substantively justified the Court can determine it to be an unjustified dismissal on the grounds of procedural unfairness. It is this branch of the test for justification of dismissals from which most controversy has arisen. This limb involves an examination of the manner in which the dismissal was conducted. Where a contract contains a procedure for dismissals, this must be adhered to by the parties. ${ }^{25}$ However, even in the absence of express contractual provisions the implied term of mutual trust and confidence requires that the redundancy be conducted in a manner which is fair and reasonable. ${ }^{26}$ It is in this sense, therefore, that the implied term is the foundation of procedural fairness. In a redundancy situation the requirement of procedural fairness may call for a consideration of such things as: ${ }^{27}$

(1) consultation with staff;

(2) warning to the authorised representative;

22 Telecom South Ltd v Post Office Union [1992] 1 ERNZ 711, 722 (CA) per Richardson J.

23 Hale $v$ Wellington, Caretakers, IUW, above $\mathrm{n} 14$.

24 Hale $v$ Wellington, Caretakers, IUW, above n 14, 157-158 per Richardson J.

25 Clough v Dunedin City Council [1992] 2 ERNZ 646, 657.

26 See Horn (ed), above n 12, para EC27.34.6.

27 See Employment Law Guide, above n 9, 316-322, 326-340. 
(3) consideration of alternatives;

(4) selection process and criteria; and

(5) counselling and support.

What is actually required will depend on the circumstances of each case. ${ }^{28}$ For example, in Aoraki it was held that where a large number of people are to be made redundant, consultation was not required for the sake of procedural fairness. ${ }^{29}$

The most controversial aspect of redundancy law in New Zealand in recent times has been whether the payment of redundancy compensation can be considered a relevant factor when considering whether the requirement of procedural fairness stemming from the implied term has been met. In Brighouse the majority of the Court held that it could, however in response to the same question four years later the Court in Aoraki held that it could not.

\section{THE DEVELOPMENT OF THE REQUIREMENT TO PAY REDUNDANCY COMPENSATION}

In 1992, the then Minister of Labour, the Rt Hon Bill Birch said, "[r]edundancy has always been a matter of negotiation between employers and employees under both previous industrial relations law and the Employment Contracts Act." ${ }^{30}$ In New Zealand there have been no enactments akin to legislation such as that which exists in England or Australia dealing with the payment of redundancy compensation. ${ }^{31}$ While this remains true, the Court's view on whether, where an employment contract is silent on the matter, there can be a requirement to pay redundancy compensation stemming from the implied duty of mutual trust and confidence, has been characterised by change. ${ }^{32}$

28 GWD Russells (Gore) Ltd v Muir [1993] 2 ERNZ 332.

29 Aoraki v McGavin, above n 1, 624 per Gault J.

30 Ferguson, above n 3, 383.

31 In England the right to redundancy compensation was introduced by the Redundancy Payments Act 1965 (UK). It is now found in the Employment Rights Act 1996 (UK), ss135-181. See R Upex Sweet \& Maxwell's Encyclopaedia of Employment Law (Sweet \& Maxwell, London, 1992) para 1.6511.6512 (Sept 1996). In Australia redundancy compensation is covered by statute, both at federal and state levels. See Peter Punch Australian Industrial Law (CCH Australia, Sydney, 1995) 923-934.

32 Redundancy compensation is used in the sense of compensation for the loss of the job. Possible reasons and policy justifications for requiring the payment of redundancy compensation are not addressed in this paper. See Lori Grantham "Toward a Right to Redundancy Compensation" (1996) 21(2) NZJIR 157. See also Wynes v Southrepps Hall Broiler Farm Ltd [1968] 3 ITR 407. 


\section{A Canterbury Hotel, etc, IUW v Fabiola Fashions Ltd ${ }^{33}$}

In this case the Union argued that an employee's dismissal by way of redundancy was unjustifiable due to the absence of any payment of redundancy compensation by the employer. There was no express requirement to pay compensation in the employee's contract. The Arbitration Court held that in the absence of a contractual entitlement to redundancy compensation the Court did not have the jurisdiction to require it, and that a failure to pay redundancy compensation could not render the dismissal unjustified. ${ }^{34}$

\section{B G N Hale E Sons Ltd $v$ Wellington, etc, Caretakers, etc, IUW ${ }^{35}$}

In this case the Court of Appeal said that procedural fairness was required to justify a dismissal for redundancy. ${ }^{36}$ The majority of the Court also held that the payment of redundancy compensation was a relevant factor in a consideration of whether or not a dismissal was procedurally justified. ${ }^{37}$

\section{Brighouse Ltd v Bilderbeck}

In this case the Court of Appeal considered the line of cases following Hale and was unanimous in upholding the requirement of procedural fairness in redundancy dismissals. However, they spilt, three to two, over the issue of whether such fairness required the payment of redundancy compensation where the contract was silent. The majority were of the view that it did, and it was the obiter statements of the majority in GN Hale $\mathcal{E}$ Sons $v$ Wellington, etc, Caretakers, etc IUW which provided the basis of their decision. Cooke $\mathrm{P}$, in the majority, confirmed that the "duty of fairness" may require the payment of redundancy compensation even in the absence of prior agreement to do so. ${ }^{38}$

Similarly, Casey J said: ${ }^{39}$

I can see no reason in law preventing the Tribunal and the Employment Court ... developing the concept of unjustifiable dismissal so as to take into account the moral obligation of a fairminded employer, to pay compensation in appropriate circumstances.

33 Canterbury Hotel, etc, IUWv Fabiola Fashions Ltd [1981] ACJ 439.

34 Canterbury Hotel, etc, IUWv Fabiola Fashions Ltd, above n 33, 441 per Williamson J.

35 Hale v Wellington, Caretakers, IUW, above $\mathrm{n} 14$.

36 Hale v Wellington, Caretakers, IUW, above n 14, 156 per Cooke P.

37 Hale $v$ Wellington, Caretakers, IUW, above n 14, 156 per Cooke P, 158 per Somers J, 159-160 per Bisson J.

38 Brighouse v Bilderbeck, above n 2, 254 per Cooke $\mathrm{P}$

39 Brighouse v Bilderbeck, above n 2, 270 per Casey J. 
Richardson J and Gault J clearly strongly disagreed with the majority's approach to the issue. Richardson J stated that "nothing said in Hale could be regarded as supporting the stance of the Employment Court" and that he could not see the dicta in Hale as a charter to depart from the rule in Fabiola Fashions. ${ }^{40}$ He said that the "imposition of redundancy obligations, where the parties have not agreed under their contract for any such provision, and the establishment of quantification criteria are surely for the legislature, not for the Courts." 41

Gault J was of the view that the law in this area needed to be "readily understandable" and "should rest not on abstract concepts and implied terms evolved through complex judgments but on straightforward application of the provisions of the Employment Contracts Act." 42 He went on to say, "[t]here is no requirement as a matter of law that the employer offer or pay compensation of redundancy when there is no contractual entitlement to do so." 43

Much debate, controversy and criticism followed the result in Brighouse. Criticism was understandably strongest from proponents of new-right economics. For example, a paper published by the Business Roundtable said: 44

By conditioning their approach on the unacknowledged assumption that the Employment Contracts Act should be read as making the smallest change in the law in any way compatible with the express provisions of the statute, and using that approach as a means of introducing a false implied term in the employment contract, the majority in Brighouse succeeded in contradicting the Act as well as the contract. In doing so the Court of Appeal exceeded the judicial function and placed itself above parliament in the formulation of social policy.

Interestingly, just as Cooke $\mathrm{P}$ and Casey $\mathrm{J}$ used their judgments in Hale as the foundation of their decisions in Brighouse, so too could Richardson P and Gault J use their dissent in Brighouse as the foundation of the majority decision in the Court of Appeal when this issue once again came before them in 1998.

40 Brighouse v Bilderbeck, above n 2, 265 per Richardson J dissenting.

41 Brighouse v Bilderbeck, above n 2, 267 per Richardson J dissenting.

42 Brighouse v Bilderbeck, above n 2, 270 per Gault J dissenting.

43 Brighouse v Bilderbeck, above n 2, 271 per Gault J dissenting.

44 Colin Howard "Interpretation of the Employment Contracts Act 1991" (New Zealand Business Roundtable/New Zealand Employers Federation, December 1995) 12. 


\section{AORAKI CORPORATION LTD V McGAVIN}

The issue of redundancy compensation and its role, if any, in procedural fairness arose again in Aoraki Corporation Ltd $v$ McGavin. ${ }^{45}$ The perceived need for a definitive statement on the law in this area was evident by the seven member bench, the first instance of this in a New Zealand employment appeal. While once again confirming that procedural fairness is required to justify a redundancy dismissal, the Court was unanimous that where a contract of employment was silent in regard to the payment of redundancy compensation, the Court could not require payment under the head of procedural fairness. In reaching this decision the Court of Appeal reversed the decision of the Employment Court on this point.

\section{A The Employment Court Decision}

Mr McGavin was a senior employee of Aoraki Corporation, most recently employed as a marketing manager, but having filled a variety of roles in his 10 years' service with the software company. He had no written contract, and in particular no contractual provisions relating to redundancy. In 1994, he was, along with 95 others, made redundant, due to Aoraki's need to restructure in the context of financial difficulties.

The Employment Court, considering an unjustified dismissal claim by Mr McGavin, decided that the dismissal was substantively justified. ${ }^{46}$ As to the requirement of procedural fairness, the Employment Court held that Mr McGavin's dismissal was procedurally unjustified ${ }^{47}$ and awarded $\$ 87,688$ in compensation.

The finding of procedural unfairness was based on flaws in various aspects of the procedure followed. ${ }^{48}$ The most notable was the finding that, given Mr McGavin's age, ${ }^{49}$ long service, the specialised nature of his skills and experience and the depressed state of the information technology industry in which he was employed, the redundancy package of three months' salary was insufficient. Accordingly the Court concluded that in terms of

45 Aoraki v McGavin, above n 1, 601.

46 McGavin v Aoraki Corporation Ltd [1996] 2 ERNZ 114, 129 (EC) per Travis J [McGavin v Aoraki].

47 McGavin v Aoraki, above n 46, 138 per Travis J.

48 The failure to consult with Mr McGavin, Aoraki's responsibility for the events which led to $\mathrm{Mr}$ McGavin's failure to receive counselling and their failure to provide reasons for the redundancy each left Aoraki in breach of their duty to act reasonably and fairly toward their employees. McGavin v Aoraki, above n 46, 136-138 per Travis J.

49 The evidence in the case suggests that Mr McGavin was over 50 years old. See McGavin v Aoraki, above $\mathrm{n} 46,131-132$ per Travis J. 
the majority decision in Brighouse, Aoraki had failed in its duty to act fairly through its failure to pay reasonable redundancy compensation. ${ }^{50}$

\section{B The Court of Appeal Decision}

The finding of procedural unfairness in the Employment Court was appealed by Aoraki and the Court of Appeal decision left no doubt that the law as it had stood following Brighouse was no longer sound.

\section{The precedent issue}

Having traversed the Employment Court decision and both the majority and minority judgments of Brighouse, the majority in Aoraki addressed the obvious precedent issue created by Brighouse. They referred to a previous decision of the Court of Appeal on the issue of precedent. ${ }^{51}$ They said that this case essentially indicated that the Court would ordinarily follow its previous decisions, however would revisit them where it considered it appropriate in the interests of justice. ${ }^{52}$

The majority acknowledged that if the Legislature were unhappy with Brighouse and the law in this area it could amend the legislation. However, they said that this: ${ }^{53}$

Would be complex and involve substantial redrafting in a situation where the argument for

the present appellant is that the interpretation of legislation is a matter for the Courts and the

construction answer in this case is straightforward and clear.

This assertion is by no means beyond question. The difficulties in interpreting this, and other parts of the Employment Contracts Act, are well recognised ${ }^{54}$ and will be discussed further below.

The Court of Appeal advanced three justifications for their decision to reconsider the law in relation to the requirement to pay redundancy compensation as part of procedural fairness. They said: 55

50 McGavin v Aoraki, above n 46, 133-134 per Travis J.

$51 \quad R v$ Hines [1997] 3 NZLR 529 (CA).

52 Aoraki v McGavin, above n 1, 616 per Gault J.

53 Aoraki v McGavin, above n 1, 616 per Gault J.

54 See Gordon Anderson "Interpreting the Employment Contracts Act: Are the Courts Undermining the Act?" (1997) 28 Cal W Int'l LJ 117, 123-124 ["Interpreting the Employment Contracts Act"].

55 Aoraki v McGavin, above n 1, 616-617 per Gault J. 
(1) It is difficult to discern a single ratio running through each of the majority judgments in Brighouse, and that the focus on Cooke P's judgment has been too strong;

(2) The President's judgment and the judgment of Casey J left the Employment Court with considerable flexibility to develop a concept of unjustifiable dismissal, as is evidenced, they say, by the judgment of Travis J in Phipps $v$ NZ Fishing Industry Board; 56

(3) Redundancy is an important area of law affecting large numbers of New Zealanders every year. It is therefore imperative that employees and employers be able to plan with confidence and determine what their respective rights and obligations are. It should lend itself to a short statement of governing principles drawn from the straightforward application of the Act.

These justifications have not gone without criticism, and have been described as "unconvincing". 57

\section{The Court of Appeal's consideration of the Employment Court decision}

Through an application of a series of principles ${ }^{58}$ the Court of Appeal concluded that the Employment Court had erred in law in its approach to the case. In reference to the award of the Employment Court of $\$ 37,688$ for future economic loss they said: ${ }^{59}$

Clearly it was wrong in law to found the award on the Court's equity and good conscience jurisdiction. It is not an independent remedy. As earlier noted, the exercise of that jurisdiction cannot be inconsistent with the Employment Contracts Act (s 104(3)). It does not allow the Employment Court when determining a personal grievance to depart from the proper interpretation of unjustifiable dismissal and unjustifiable action within the meaning of $\mathrm{s}$ 27(1)(a) and (b); to substitute another contract containing provision; or to go beyond the statutory remedy for the particular grievance.

The Court saw no evidential foundation for an award in excess of the three months' salary initially paid by the employer. ${ }^{60}$ They also held that the payment of $\$ 50,000$ for

56 Phipps $v$ NZ Fishing Industry Board [1996] 1 ERNZ 195, 208 (EC). The major concern the majority seemed to have with this decision was that it held that "a failure to inquire or consult would be fatal to justification", the effect of this being that consultation would become a mandatory requirement, rather than a relevant consideration.

57 Kenneth Johnston "Redundancy: Swings and Roundabouts" (1998) 5 ELB 86, 87 ["Redundancy: Swings and Roundabouts"].

58 Aoraki v McGavin, above n 1, 617-620 per Gault J.

59 Aoraki v McGavin, above n 1, 623 per Gault J. 
humiliation and distress must be taken to have been awarded to cover the trauma from loss of the job as well as the trauma of the manner in which the dismissal was carried out. ${ }^{61}$ They therefore set it aside and made an award of $\$ 15,000 .{ }^{62}$

\section{REASONS FOR THE COURT'S CHANGE IN APPROACH}

This paper will not attempt to provide a comprehensive discussion of all aspects of Aoraki, as this can be found elsewhere. ${ }^{63}$ It will however identify and examine key components of the reasoning in the decision, focusing predominantly on the majority judgment, but also considering the minority judgment of Thomas J. In comparing and contrasting the Aoraki judgments with those in Brighouse, it will also attempt to highlight factors more implicit in the judgments which lead to the change in the Court's approach.

\section{A The Intention of the Act}

The intention of an Act is a key factor in the interpretation of statute in New Zealand. ${ }^{64}$ As the majority in Aoraki put it, "[t]he responsibility of the Courts is to give effect to the intent of Parliament as expressed in the statute." 65 This section will discuss at a relatively general level the relevance of the intention of Parliament, some of the difficulties in interpreting the Employment Contracts Act, and how the Courts perceived the intention of Parliament in relation to the Act. There are many aspects of the reasoning in Aoraki and Brighouse where the Courts took differing views on what the "intention of Parliament" was. Several of the key areas will be discussed in more detail below.

\section{Statutory interpretation}

In Aoraki the Court accepted that the issue was essentially one of "statutory construction." 66 The accepted approach to statutory interpretation in New Zealand is the purposive approach. This means that legislation should receive "such fair, large, and

60 Aoraki v McGavin, above n 1, 623 per Gault J.

61 Aorakiv McGavin, above n 1, 623 per Gault J.

62 Aorakiv McGavin, above n 1, 624 per Gault J.

63 See Gordon Anderson "Recent Case Comment: Aoraki Corporation Ltd v McGavin" (1998) 5 ELB 96101. See also Richard Francois "Redundancy, Black Letter Law and the Obligation of Fair Dealing" (1998) 8(3) Auck U LR 932.

64 See JF Burrows Statute Law in New Zealand (2 ed, Butterworths, Wellington, 1999) 118-119 [Statute Law in New Zealand].

65 Aoraki v McGavin, above n 1, 612 per Gault J.

66 Aoraki v McGavin, above n 1, 616 per Gault J. 
liberal construction and interpretation as will best ensure the attainment of the object of [the Act and provision] according to its true intent, meaning, and spirit." 67

The interpretation of the Employment Contracts Act poses some difficulties for the courts. A key indication of the intention of Parliament can be found in the long title of the Act. However the Employment Contracts Act also contains further expressions of intent in each part of the Act, through the inclusion of objects clauses. In the case of Parts III and $\mathrm{IV}, 68$ these seem inconsistent with the notion of freedom of contract and, proponents of contract at will would argue, efficiency considerations. ${ }^{69}$ The difficulty for the courts therefore is how to give effect to these seemingly conflicting intentions of Parliament. This difficulty arises, in part, due to the fact that the Act is a compromise between the strict contractual approach to employment law, and the employee protection approach.

The words used in the Employment Contracts Act also pose interpretation difficulties. The words of the section are the most important aspect for the purposes of statutory interpretation. ${ }^{70}$ In the case of section 27 difficulty arises from the fact that the meaning of "unjustified" and "dismissal" have been left to the courts to develop. What constitutes a "justified" dismissal is at issue in Aoraki, but the meaning of "dismissal" has also been an area where the courts have had some difficulty in interpreting the meaning of the words of the Act. ${ }^{71}$

\section{Intention of the Act as determined in Aoraki}

The majority in Aoraki considered the long title of the Act and indicated that it emphasised notions of contractual freedom and a desire for an efficient labour market. ${ }^{72}$

They then considered the scheme of the Act, a contextual consideration, and following this determined that: ${ }^{73}$

67 Acts Interpretation Act 1924, s5(j). For further discussion see Statute Law in New Zealand, above n 64, 118-119. This section has now been replaced by Interpretation Act 1999, s5.

68 The personal grievance and disputes procedures.

69 See Richard A Epstein "Employment Law - Courts and Contracts" (New Zealand Business Roundtable, Wellington, 1996) 15 ["Courts and Contracts"].

70 Statute Law in New Zealand, above n 64, 119.

71 In particular, the issue of whether the expiry of a fixed term contract constitutes a dismissal or not has been an area subject to change. See Smith $v$ Radio $i$ Ltd [1995] 1 ERNZ 281, and subsequently, Auckland College of Education v Hagg, above n 20.

72 Aoraki v McGavin, above n 1, 609 per Gault J.

73 Aoraki v McGavin, above n 1, 611-612 per Gault J. 
The 1991 Act represents a substantial departure from the collectivist principles of previous industrial relations legislation in favour of a model of free contractual bargaining. In adopting a contractual approach, however, the statute also recognises that the nature of employment and the employment relationship differentiate employment contracts from conventional commercial contracts governing the supply of goods and services. The Act departs from the common law of contract in setting the yardstick of unjustifiable dismissal and unjustifiable action, in specifying procedures and remedies, and in other respects.

However, they noted, in regard to the personal grievance procedures that "the context in which they operate is sharply changed by the emphasis in the 1991 Act on contractual freedom." 74

Clearly, therefore, the Court in Aoraki saw the intention of the Employment Contracts Act as a shift towards the application of the ordinary rules of contract to employment contracts, and in doing so, discounted somewhat the effect of the inclusion of the personal grievance procedures, and the objects clause of Part III of the Act.

Such an interpretation of the intention of Parliament was clearly a decisive factor in the Aoraki decision. The Court said, in relation to a requirement to pay redundancy compensation where the contract is silent, that to do so would "erode the statutory emphasis on free negotiation of employment contracts." 75 Richardson J took the same view in Brighouse when, on the same point, he said to do so would "run counter to the statutory intent." 76

\section{Intention of the Act as determined in Brighouse}

In Brighouse the intention of Parliament does not receive a similar extended analysis. It is difficult to argue that the Act did not represent a move towards a more contractual approach in employment law, however the Act passed was somewhat of a compromise. ${ }^{77}$

It is apparent, due to the general tenor of the majority judgments in Brighouse, that they did not feel a need to import the contractual principles of the Employment Contracts Act into Part III to the same extent as the majority in Aoraki. Cooke P, for example, said "[t]he emphasis on efficiency and market forces is thus accompanied by a reaffirmation and broadening of the scope of the personal grievance procedures."78 They accorded

74 Aorakiv McGavin, above n 1, 612 per Gault J.

75 Aorakiv McGavin, above n 1, 620 per Gault J.

76 Brighouse v Bilderbeck, above n 2, 258 per Richardson J dissenting.

77 See for example the discussion in below part VI B The Personal Grievance Jurisdiction. See also Employment Contracts Act 1991, s 19.

78 Brighouse v Bilderbeck, above n 2, 251 per Cooke P. 
significant weight to the inclusion of the personal grievance procedures essentially unchanged from previous legislation. ${ }^{79}$

Casey $\mathrm{J}$ in his judgment makes it clear that the Court's approach was obviously considerably different to that taken in Aoraki. He mentions that the award of redundancy compensation may be seen to be "contrary to the philosophy of the Employment Contracts Act", but goes on to say that the personal grievance procedure is in place to "afford a way of redressing the balance" where employees have no real power. ${ }^{80}$

What the Court determines the intention of Parliament to be, will affect the interpretation of the statute. Accordingly it can be seen that while the Employment Contracts Act signalled a move towards a more individual and contractual based approach to employment law it is a compromise. It retained the personal grievance jurisdiction and collective agreements, and therefore the Act is an uneasy mix of these conflicting viewpoints. In Aoraki it seems the Court may have accorded greater emphasis to what they saw as the intention of the Act as a whole, a broad intent that pervaded all parts of the Act. This is in contrast to Brighouse, where greater emphasis was placed on the specific intent of Part III.

\section{B The Personal Grievance Jurisdiction}

During the drafting and enactment of the Employment Contracts Bill there was much political debate and lobbying over whether the personal grievance jurisdiction should be retained. The government received conflicting policy advice, the Department of Labour supporting its inclusion, while on the other hand, Treasury was staunchly against it. ${ }^{81}$ The result was that the Employment Contracts Act retained the personal grievance jurisdiction essentially unchanged, ${ }^{82}$ and it was extended to cover all employees. ${ }^{83}$

It is also worth recognising that the original Bill contained a clause, the effect of which would have been to reduce substantially the relevance of procedural fairness where the dismissal was substantively justified. This clause was not included in the Act, thus clearly

79 A more detailed discussion of the inclusion of the personal grievance procedures, and the intended effect of this is discussed at below section VI B The Personal Grievance Jurisdiction.

80 Brighouse v Bilderbeck, above n 2, 269 per Casey J.

81 See Pat Walsh and Rose Ryan "The Making of the Employment Contracts Act" in Raymond Harbridge (ed) Employment Contracts: New Zealand Experiences (Victoria University Press, Wellington, 1993) 13.

82 John Hughes "The Employment Court, 'Judicial Activism', and the Coalition Agreement" (1997) 28 Cal W Int'l LJ 167, 187.

83 Previously it had covered only parties to an award, that is, union members. 
indicating that the concept of procedural fairness was intended to remain following the Employment Contracts Act. ${ }^{84}$

The problem for the courts has been how to apply the re-enacted provisions under the Employment Contracts Act. Two different approaches are apparent after Brighouse and Aoraki.

\section{The approach in Brighouse}

The approach apparent in the judgments of the majority of the Court in Brighouse is that of a reapplication of the law as it had been prior to the Employment Contracts Act. This approach is most expressly evident in the judgment of Cooke P. He noted that the Employment Contracts Act did not curtail the personal grievance jurisdiction which had been part of the law since $1970 .{ }^{85} \mathrm{He}$ also noted that the jurisdiction had been extended under the new legislation. ${ }^{86}$ Most revealing however, is the following passage: ${ }^{87}$

The Act was enacted on 7 May 1991. The availability of the discretionary personal grievance remedies in redundancy cases had been demonstrated in the previous year in the well known case of G N Hale \& Son Ltd $v$ Wellington, etc, Caretakers, etc, IUOW ... If Parliament had intended to prevent such a result in future, it is surprising that the 1991 Act did not so provide. There is nothing in the Act to indicate any such intention.

This approach accords a greater weight to the perceived purpose of the personal grievance jurisdiction. Cooke P said, "[t]he philosophy reflected in this part of the Act is that the common law may well be inadequate to achieve justice between employer and employee." 88 (Emphasis added.)

Such an approach accords with generally accepted principles of statutory interpretation. It is considered that where new legislation re-enacts provisions drawn from the earlier legislation which it replaces, it is assumed that Parliament was aware of the way in which the courts had interpreted those provisions and, by re-enacting them unchanged, was endorsing that interpretation. ${ }^{89}$ Even so, this aspect of the reasoning in

84 Employment Contracts Bill 1990, cl 17.

85 Brighouse v Bilderbeck, above n 2, 251 per Cooke P.

86 Brighouse v Bilderbeck, above n 2, 251 per Cooke P.

87 Brighouse v Bilderbeck, above n 2, 252 per Cooke P.

88 Brighouse v Bilderbeck, above n 2, 253 per Cooke P.

89 John Burrows Statute Law in New Zealand (Butterworths, Wellington, 1992) 170, in Hughes, above n 82, 187. 
Brighouse has been subject to a great deal of criticism from supporters of the new-right as it is said to frustrate the policy of the Act. ${ }^{90}$

\section{The approach in Aoraki}

The Court in Aoraki most certainly did not subscribe to the theory described above. They, like the supporters of the new-right, considered that the re-enactment of the personal grievance procedures unchanged did not justify their application in the same manner as they had been prior to the Employment Contracts Act.

Richardson J, in his dissenting judgment in Brighouse, made it quite clear that he did not concur with Cooke P's finding that Parliament had affirmed the Court's approach in Hale. He said: ${ }^{91}$

[It cannot] be said that the enactment of the personal grievance provisions of s 27 of the Employment Contracts Act 1991 was a legislative endorsement of the interpretation given to the expression "unjustifiably dismissed" in its predecessor (s 210 of the Labour Relations Act 1987) by the then Labour Court post-Hale. Mere repetition of a legislative expression cannot warrant any inference of that kind and in the 190 pages of Hansard on the Employment Contracts Bill (vol 514 of the Parliamentary Debates) there is no discussion of the test of unjustifiable dismissal, no reference to Hale and no mention of the interpretation by the Courts of the previous legislation.

Likewise, as noted above, in Aoraki the majority of the Court said that although the personal grievance provisions have been re-enacted, "the context in which they operate is sharply changed by the emphasis in the 1991 Act on contractual freedom. ${ }^{92}$

It can be seen therefore that the Court in Aoraki saw it necessary to reinterpret the provisions in their new context, rather than the simple reapplication as considered justified in Brighouse. In doing so, the manner in which they operate was changed significantly to reflect the broad notions of contractual freedom in the Act.

90 Howard, above n 44, 3 .

91 Brighouse $v$ Bilderbeck, above n 2, 265-266 per Richardson J dissenting. Given the pace at which the Employment Contracts Bill was passed, and the negative impact this had on the ability of Parliament to fully debate the Bill, one might question the merit of reliance on such debate. See generally Ellen J Dannin Working Free: The Origins and Impact of New Zealand's Employment Contracts Act (Auckland University Press, Auckland, 1997) 88-114 and 152-163.

92 Aoraki v McGavin, above n 1, 612 per Gault J. 


\section{The Nature of the Employment Relationship}

The nature of the employment relationship is an area of considerable debate, and an area where the ideologies of the Court in Brighouse and Aoraki appear to differ. Essentially there are two ways to categorise the employment relationship and employment contracts.

\section{$1 \quad$ Employment at will ${ }^{93}$}

Employment at will is an approach which finds support with those who subscribe to the "new-right" ideological perspective. It operates on the assumption that there is no contractual imbalance inherent in the employment relationship. It is grounded on efficiency justifications with an employer free to adjust staffing levels to meet production, thus allowing them to maximise operating efficiency. Essentially under this view therefore, labour is like any other commodity, bought and sold subject to the constraints of supply and demand in the absence of any inherent bargaining inequality.

Under this approach there is no need to justify a dismissal on substantive grounds, and procedurally, all that would be required in the common law context would be the provision of reasonable notice. ${ }^{94}$ Accordingly, supporters of this view are likely to agree with the tenor of the Employment Contracts Act, however would consider Parts III and IV unnecessary, and undesirable. ${ }^{95}$

\section{Employment security and employment protection}

Under employment security it is argued that employees have an investment in their job, both financial and psychological, requiring protection. Encompassed by this is the notion that since most people are reliant on employment as a source of financial security, their employment opportunities should not be unnecessarily restricted by unjustified conduct. ${ }^{96}$ Such protection also acknowledges, it is argued, the fact that in modern society individuals are also reliant on employment as a source of psychological security in the sense of self-esteem, self-identity, friendships and other such things. As a result of the reliance individuals place on employment, the burden of a dismissal falls more heavily on them than on the employer. This line of theory works on the basis that there is an inherent

93 The following is a brief discussion of the theory behind employment at will. For a detailed discussion see Richard Epstein "In Defence of the Contract at Will" (1984) 51 U Chi L Rev 947-982.

94 See New Zealand Business Roundtable and New Zealand Employers Federation "The Labour/Employment Court: An analysis of the Labour/Employment Court's approach to the interpretation and application of employment legislation" (NZBRT/NZEF, December 1992) 40-41 ["A Study of the Labour/Employment Court"].

95 Roger Kerr "The New Zealand Employment Contracts Act: Enactment, Performance, and Implications" (1997) 28 Cal W Int'1 LJ 89, 99-102.

96 Employment Law Guide, above n 9, 212-213. 
power imbalance in the employment relationship, in part due to the employee's greater reliance on obtaining and retaining employment.

\section{The approach in Aoraki}

In Aoraki the majority of the Court set out the long title of the Act and noted that it emphasised "that employment issues are a matter of contract, where the types of contract and the content are essentially for the parties to freely negotiate." 97 In saying this it is implicit that any imbalance of power in the relationship is ignored, for if it were acknowledged, how could there be "free negotiation"? Later in their judgment the Court acknowledged that "the statute also recognises that the nature of employment and the employment relationship differentiate employment contracts from conventional commercial contracts governing the supply of goods and services." 98 They acknowledged the tension between a contractual approach and social and economic concerns. ${ }^{99}$

However, despite acknowledging the recognition by the Act of the special character of the employment relationship it is apparent that their paramount concern was to give effect to the broad intention of Parliament. That intent, as discussed above, was determined by them to be the promotion of contractual ideals and as a result the recognition by the statute that the employment relationship is special, seemed to be read down so as to be more in line with the contractual ideals of the Act.

\section{The approach in Brighouse}

In Brighouse the majority is quite clear that they see the purpose of the personal grievance procedures as a mechanism to redress the imbalance in the employment relationship, and apply them as such.

Cooke P said, "the very raison d'être of the statutory jurisdiction was the perceived inadequacy in many cases of common law contractual rights and remedies."100 Interestingly, he quotes and adopts Richardson J's judgment in Telecom South Ltd $v$ Post Office Union ${ }^{101}$ where both the special nature of the employment relationship, and the function of the personal grievance jurisdiction to redress the imbalance in it are acknowledged. ${ }^{102}$ Similarly, as mentioned above, Casey J was of the opinion that the

97 Aoraki v McGavin, above n 1, 609 per Gault J.

98 Aoraki v McGavin, above n 1, 612 per Gault J (emphasis added).

99 Aorakiv McGavin, above n 1, 612 per Gault J.

100 Brighouse v Bilderbeck, above n 2, 253 per Cooke P.

101 Telecom South $v$ Post Office Union, above n 22, 722 per Richardson J.

102 Brighouse v Bilderbeck, above n 2, 252 per Cooke P. 
personal grievance procedure affords a way of redressing the imbalance of bargaining power. ${ }^{103}$

\section{The Effect of Section 46(3)}

Section 46 is one of the few areas in the Employment Contracts Act 1991 where redundancy is mentioned. Of particular note is subsection (3) which reads:

Without limiting the generality of subsection (1) of this section, where a provision of any contract deals with the issue of redundancy but does not specify either the level of redundancy compensation payable or a formula for fixing that compensation, neither the Tribunal nor the Court shall have the jurisdiction to fix that compensation or specify a formula for fixing that compensation.

There has been much debate over the meaning and, more importantly, the effect of this section. ${ }^{104}$ Generally speaking two main lines of thought have become apparent.

\section{The broad view}

Proponents of this stance take the view that section 46(3) manifests the legislature's intent that the courts should not fix levels of redundancy compensation. Under this view the section's effect is a more general one, rather than being limited to issues which arise under the disputes jurisdiction. The majority in Aoraki mentioned this section and noted that it posed a constraint in redundancy matters. ${ }^{105}$ They said, "[t]he 1991 Act leaves any redundancy compensation arrangements to the bargaining processes under the statute and goes the further step of expressly excluding the Tribunal and the Employment Court from fixing the redundancy levels or formulas where there is a dispute over the interpretation of a redundancy provision."106 In his separate judgment, Thomas J summarised the view taken by the Court well. He said that: ${ }^{107}$

103 Brighouse v Bilderbeck, above n 2, 269 per Casey J.

104 The debate can be followed over a series of articles in the Employment Law Bulletin. The debate started with the article by Peter Zwart "Redundancy Compensation Reconsidered" (1992) 5 ILB 47; this was replied to by Don MacKinnon, Paul McBride "Correspondence" (1992) 6 ILB 62, Kenneth Johnston "Redundancy ... Again" (1992) 8 ILB 82, Isaacus Adzoxornu "Jurisdiction to Fix Quantum of Redundancy Compensation under the EC Act" (1992) 8 ILB 83, Isaacus Adzoxornu "Jurisdiction to Fix Quantum of Redundancy Compensation under the EC Act: Part II" (1993) 1 ELB 4, "Redundancy: Swings and Roundabouts", above n 57.

105 Aoraki v McGavin, above n 1, 611 per Gault J.

106 Aoraki v McGavin, above n 1, 621 per Gault J.

107 Aoraki v McGavin, above n 1, 628 per Gault J. 
It would surely follow that, if the industrial tribunals cannot fix the level of compensation or a formula for fixing it when the issue of redundancy has been dealt with in the employment contract, Parliament cannot have intended that the same tribunals would have the jurisdiction to do just that where the contract is silent on the issue.

\section{The narrow view}

There is however an alternative, conflicting interpretation of section 46(3) and its effect under which the effect of the section is restricted to matters which arise under Part IV of the Act, the disputes jurisdiction. Proponents of the narrow view argue that section 46(3) was enacted to overturn a line of cases, ${ }^{108}$ which had held that, where a redundancy clause was not specific as to the quantum of redundancy compensation to be paid, the parties were entitled to take a dispute of right, and that in appropriately worded clauses the court had the jurisdiction to fix the terms of the redundancy compensation. ${ }^{109}$ They argue that Parliament must be taken to have known of the GN Hale $\mathcal{E}$ Son Ltd $v$ Wellington Caretakers etc IUW $W^{110}$ decision, and that since there is no section 46(3) equivalent in Part III of the Act, the effect of section 46(3) must have been intended to be limited to Part IV of the Act, to which it expressly applies. ${ }^{111}$ This seemed to be the interpretation preferred by Cooke P in Brighouse, where he referred to section 46(3) and noted that its effect was to alter previous redundancy law. He took the view that it limited the ambit of the Court in disputes, however noted that a broad discretionary power remained under the personal grievance jurisdiction. ${ }^{112}$

Clearly the Court in Aoraki favoured the broad view of section 46(3) and their interpretation of the rationale behind and effect of section 46(3) is considered a "powerful influence" in their decision. ${ }^{113}$

\section{E The Implied Term of Mutual Trust and Confidence}

The major point of difference between the Courts in Aoraki and Brighouse is not whether the implied term of mutual trust and confidence exists in employment contracts, but rather what rights and obligations the term encompasses. In Aoraki the Court saw no

108 See Horn (ed), above n 12, para EC46.05.

109 Wellington etc Local Bodies Officers IUWv Westland Catchment Board [1988] NZILR 1708.

110 Hale $v$ Wellington, Caretakers, IUW, above $\mathrm{n} 14$.

111 Isaacus Adzoxornu "Jurisdiction to Fix Quantum of Redundancy Compensation under the EC Act" (1992) 8 ILB 83, but see GP Rossiter "Redundancy Dismissal and Procedural Fairness - The Establishment of an Extra-Contractual Entitlement to Compensation" (1996) 2 NZBLQ 175, 196.

112 Brighouse $v$ Bilderbeck, above n 2, 252 per Cooke P.

113 Employment Law Guide, above n 9, 489. 
basis for extending the term of mutual trust and confidence to a requirement to pay redundancy compensation. To do so, they say, would: ${ }^{114}$

(1) alter the substantive rights and obligations on which the parties agreed;

(2) change the economic value of their overall agreement; and

(3) erode the statutory emphasis on the free negotiation of contracts.

There is however an apparent inconsistency in their approach, for earlier in their judgment they said the term extends to a requirement to provide reasonable notice ${ }^{115}$ and went on to say that fair treatment may call for a consideration of the following procedural matters: 116

(1) counselling;

(2) career advice;

(3) financial advice;

(4) retraining and related financial support; and

(5) "other considerations".

The inconsistency arises therefore, due to the fact that the three justifications the Court provides for not extending the term to require the payment of redundancy compensation are also true of the procedural matters listed above that the Court are prepared to extend the term to require. It is not clear why the Court considers that the payment of redundancy compensation, and these other procedural matters should receive different treatment.

In formulating the content of the implied term, the Courts use the principle of reasonableness and consider what it is open to the fair and reasonable employer to do. The difficulty with this approach is that what is "reasonable" depends entirely on what the Court considers it to be.

\section{F The Perceived Need for Certainty}

A perceived need for certainty in the law in this area was, as stated above, a key factor in the decision of the majority of Aoraki to reconsider Brighouse. However, not only was it a

114 Aoraki v McGavin, above n 1, 620 per Gault J.

115 Aoraki v McGavin, above n 1, 618-619 per Gault J.

116 Aoraki v McGavin, above n 1, 619 per Gault J. 
key factor in the Court's decision to reconsider Brighouse, it was also clearly a factor which materially influenced the outcome of the Aoraki decision.

\section{The approach in Aoraki}

The Court in Aoraki discussed Part VI of the Act which sets up the specialist institutions. In doing so they noted section 76(a) which they said "explicitly recognises, "that the nature of employment contracts is such that the parties to employment contracts from time to time require the assistance and certainty that can be provided by a specialist Court"."117 A more definitive illustration of their view comes later when, in justifying their decision to revisit the law, they said "it is imperative that employees and employers be able to plan with confidence and determine what their respective rights and obligations are." 118

Certainty is a quality of the law strongly advocated by those supporting the new-right philosophy. Roger Kerr recently criticised New Zealand's senior judges who he said "seem perfectly comfortable with arbitrariness and unpredictability."119

Aoraki is regarded as a case which results in greater certainty. Associate Professor Bill Hodge of Auckland University, commenting on Aoraki, wrote that an application of "black letter" law and contract promotes values of "certainty and reliance" and that "the less predictable judicially determined canons of fairness, justice, equity, and good conscience" promote "bespoke justice, tailored to the parties' circumstances."120

\section{The approach in Brighouse}

It could not be clearer that Cooke P, in particular, in his decision in Brighouse does not share the views of Roger Kerr in relation to certainty. He acknowledged that the state of the law, as it was then, is complained of by employers because it gives rise to uncertainty, and even acknowledged that there "may be some truth in that."121 His rebuttal to this concern contained two main strands of reasoning.

117 Aoraki v McGavin, above n 1, 611 per Gault J (emphasis added).

118 Aoraki v McGavin, above n 1, 617 per Gault J.

119 Roger Kerr "Judging the Judiciary" [1998] NZLJ 329 ["Judging the Judiciary"].

120 Horn (ed), above n 12, 1C 8/6/98 Update (Redundancy - welcome clarity editorial).

121 Brighouse v Bilderbeck, above n 2, 256 per Cooke P. 
The first was that certainty would result through consistent application of the law. He referred to Telecom South Ltd $v$ Post Office Union ${ }^{122}$ and Air New Zealand v Johnston ${ }^{123}$ which he said emphasised that: ${ }^{124}$

It is the responsibility of the Employment Court and the Employment Tribunal to arrive at a pattern of reasonably consistent awards, and that a corollary of the absence from the New Zealand legislation of fixed limits is that moderation would have been expected by Parliament in the exercise of this jurisdiction.

As a result he felt that industry standards and therefore, certainty would emerge. ${ }^{125}$

Further to this, even if his decision did create uncertainty, he did not view this as a concern. It was his view that "so far as there is an uncertainty problem it is a product of the statutory unjustifiable dismissal regime, open-textured, without monetary limits, and largely without monetary formulae." ${ }^{126} \mathrm{He}$ went on to add that "the field is not an easy one, but it is not for us to try and render certain that which the legislation has left flexible." 127

Clearly therefore the majority in Aoraki and Cooke P in Brighouse were entirely at odds with what their role was in terms of giving effect to certainty, and further, at odds as to whether there was certainty in the law following Brighouse.

Ironically, the Court of Appeal purported to effect certainty through yet another major change in this area. Following Brighouse employers and employees, in reaction to and in reliance on the decision, clearly took rational steps to ensure certainty in their particular redundancy situations by specifying the amount of compensation, if any, which would be payable in their contracts. ${ }^{128}$

122 Telecom South $v$ Post Office Union, above $\mathrm{n} 22$.

123 Air New Zealand v Johnston [1992] 1 NZLR 159 (CA).

124 Brighouse v Bilderbeck, above n 2, 256 per Cooke P.

125 For an analysis of awards by the Employment Court and Tribunal see Tony Couch "Statistics and Comment" and Paul Stapp "The Employment Tribunal in 1998" in Employment Law Conference (New Zealand Law Society, Wellington, 1998).

126 Brighouse v Bilderbeck, above n 2, 256 per Cooke P.

127 Brighouse v Bilderbeck, above n 2, 256 per Cooke P.

128 Analysis of collective employment contracts revealed that in June 1995, 49 per cent specified the level of redundancy compensation payable (including that none would be paid), by June 1996 this had risen to 57 per cent and by June 1999 stood at 75 per cent. Raymond Harbridge, Aaron Crawford, Peter Kiely "Employment Contracts: Bargaining Trends \& Employment Law Update 1998/99" (Victoria University of Wellington, Wellington, 1999) 53. 
The law has returned to a position where if the contract is silent as to redundancy compensation there will be none payable. Those employers who agreed, on the basis of Brighouse, to include a clause specifying that redundancy compensation would be paid, rather than run the risk of the courts determining a suitable payment, will of course be bound to fulfil that obligation. ${ }^{129}$ However, the decision in Aoraki means that these contractual clauses were unnecessary because, if employers had left their contracts silent on the issue, the courts would no longer require them to make a payment for redundancy compensation. This perhaps illustrates that a degree of consistency in our law is equally as desirable as the certainty sought by the majority in Aoraki.

\section{G Judicial Politics}

From the discussion above it should be apparent that employment law is a highly political and ideologically driven area of the law. Although the judiciary are popularly perceived not to be influenced by their political or ideological values, ${ }^{130}$ it is difficult to imagine how, in such a politically and ideologically charged area, the judiciary can isolate themselves from such beliefs.

It has been argued that any political or ideological differences in the judiciary had a minimal effect on the outcome of employment law litigation prior to 1991 due to the highly regulated nature of industrial relations. However, it is suggested that the removal of such regulation has allowed the political and ideological ideals of the judiciary to become more evident. ${ }^{131}$

It was said following Brighouse that: ${ }^{132}$

The judgments in the Court of Appeal do however reveal a strong division within the Court on the nature of the contractual relationship, and on the possible role of the Court in relation to wider questions of social policy. Richardson has clearly been attracted by elements of the law and economics rhetoric and a classical notion of contract. Cooke on the other hand appears to be more cognisant of the need to deal with the realities of the employment

129 The effect of s19(4) of the Employment Contracts Act 1991 is such that on the expiry of a collective employment contract the terms of that contract become embodied in an individual employment contract. Therefore employees will be able to retain their redundancy benefits should they wish to do so.

130 Contrast J A G Griffith The Politics of the Judicary (4 ed, Fontana Press, London 1991) and David Pannick Judges (Oxford University Press, New York, 1988).

131 Wendy Davis "Judges and the Politics of Employment Law [1994] LLM Research Paper 10-11. Available at Victoria University Law Library.

132 Gordon Anderson "Recent Case Comment - Brighouse Ltd v Bilderbeck" (1994) 8 ELB 120, 123. 
relationship, and to take account of inequalities of bargaining power, a position that involves a more liberal interpretation of the Employment Contracts Act.

In Brighouse Cooke P quotes and adopts ${ }^{133}$ a passage of Richardson J's judgment in Telecom South Ltd $v$ Post Office Union, ${ }^{134}$ which appeared to accord more with the approach adopted by the majority of the Court in Brighouse than Richardson J's dissent. In his dissent Richardson J referred to the statement and said that it had been intended in a narrower sense than the Employment Court had taken in this instance. ${ }^{135}$

If Richardson P has been attracted by the "law and economics rhetoric", it seems this has not always been the case. In addition to his statements in Telecom South Ltd $v$ Post Office Union, he has also revealed aspects of his ideological perspective in extra-judicial writing. In one piece he said: ${ }^{136}$

History tells us that in the absence of any organisation there is too great a risk of inequality of bargaining power, of exploitation of workers, and of damage to the social fabric. There are clear social equity considerations and obvious economic implications. As well as economic survival, employment often plays a central part in determining whether individuals are able to achieve many of their aspirations. Equally important for many people, a job is closely linked to feelings of self-worth and dignity. For employers too, and the wider good of society, the labour market should function fairly and efficiently.

Whether or not judicial politics and ideological perspectives have led to it, there seems to have been a change in the approach of the Court of Appeal to employment law under the Richardson P led bench. Given that it is considered the President can "influence the tenor and makeup of the Court"137 this is not surprising. Cooke P was regarded as liberal in a variety of areas, and Richardson P more conservative. ${ }^{138}$ Aoraki has been described as one in a series of cases at Court of Appeal level which take a more conservative approach, and "emphasising the clear intention of the legislature that the ordinary law of contract be applied in the industrial area." 139 With Richardson as President, this trend towards a more

133 Brighouse v Bilderbeck, above n 2, 254 per Cooke P.

134 Telecom South $v$ Post Office Union, above n 22, 722 per Richardson J.

135 Brighouse v Bilderbeck, above n 2, 267 per Richardson dissenting.

136 Sir Ivor Richardson "The Role of the Courts in Industrial Relations" (1987) 12 NZJIR 113.

137 "Interpreting the Employment Contracts Act ", above n 54, 139.

138 "Interpreting the Employment Contracts Act ", above n 54, 139.

139 "Redundancy: Swings and Roundabouts", above n 57, 87. 
conservative application of employment law in the Court of Appeal could be expected to continue. ${ }^{140}$

\section{CONCLUSION}

The law relating to the requirement to pay redundancy compensation, in the absence of an express contractual term to that effect, is a difficult area. The changing nature of the law, and in particular, the conflicting decisions of the Court of Appeal in Brighouse and Aoraki are illustrative of this fact.

At the heart of this legal issue is the implied term of mutual trust and confidence. It is an undefined term, and while both the Court in Aoraki and the Court in Brighouse acknowledge its presence in employment contracts, they differ as to its effect. The point of difference between the two Courts is the extent to which they are prepared to extend this term, and their view as to what rights and obligations the term imposes on the parties to an employment contract.

Just as the implied term of mutual trust and confidence is undefined, so too is the concept of "unjustified dismissal". Like the implied term of mutual trust and confidence, it is determined with reference to the concepts of reasonableness and moral justice.

For the Courts, the difficulty of the undefined nature of the concepts with which they are dealing is only made more difficult by the seemingly conflicting philosophies of the Employment Contracts Act. On the one hand, it is generally accepted that the Act signals a move away from collectivism and towards a more contractual approach to employment law. However on the other hand the retention of the personal grievance procedures unchanged signals a recognition that a degree of employee protection is required. It has been left entirely to the courts to juggle these conflicting principles and determine how they were intended to interact.

Aoraki has been heralded as the end of judicial activism and a return to certainty in employment law. ${ }^{141}$ One might suggest that Aoraki was in itself an example of judicial activism. However, regardless of this, the result in Aoraki does not necessarily mean that the decision in Brighouse was incorrect. This paper has shown that the area law in question is surrounded by debate. The flexible and malleable characteristics of the concepts with which the Court is dealing means that much depends on the approach of the judiciary to them. Generally there are valid justifications for both the approach taken by the Court in Aoraki, and the Court in Brighouse. One's view on which approach is the correct one is a matter which depends largely on one's political and ideological perspective.

140 See "Interpreting the Employment Contracts Act ", above n 54, 139-140.

141 A J Geare "Full Circle? The continuing saga of redundancy legislation" (1999) 24(1) NZJIR 75. 
While there are many reasons for the change in the Court's approach in this area, this paper suggests that the predominant factor leading to the change was a different interpretation of the perceived intention of Parliament, as expressed in the Employment Contracts Act 1991 and, perhaps, a change in the political and ideological perspective of the Court of Appeal.

This appears to be an area of the law where there will always be debate. It involves a consideration of the competing needs of the employee and the employer. It involves a balancing of, on the one hand, the social and economic needs of the employee, and on the other, the managerial prerogative of the employer to manage their business efficiently. In determining how to apply the law in this area, it is inevitable, to a certain extent, that the Court will engage in making social policy judgements.

Currently, the state of the law is such that it is clear that the law does not require a payment of redundancy compensation where a contract is silent on that matter. However, with an election looming and, at the time of writing, a change in government likely how long will the law remain in its current state? Should there be a Labour/Alliance coalition it is almost certain that there will be changes to the employment legislation. Such change would come almost certainly in a move to promote collective bargaining, and possibly a shift away from the individual contractual ideals of the Employment Contracts Act. ${ }^{142}$

Given the Court of Appeal's view that the personal grievance procedures need to be read in light of the context in which they operate, could we once again see change in this area? Surely further instability in the law would be undesirable. Possibly not however, in the eyes of those who feel that Aoraki has effected an undesirable change in our law.

\section{POST-SCRIPT}

Since the time of writing an election has lead to the formation of a Labour/Alliance coalition government. ${ }^{143}$ As anticipated this was closely followed by the introduction of new labour relations legislation in the form of the Employment Relations Bill. The Employment Relations Bill was heralded as marking a "new era in employment relations" by the Labour coalition, ${ }^{144}$ however was touted as a return to the bad old days by the opposition. ${ }^{145}$ While the Bill clearly promotes support for collective bargaining the writer is not of the opinion that it can fairly be likened to the employment legislation prior to 1991 as it lacks the distinctive flavours of compulsory unionism and structured bargaining

142 See "Statement of Employment Policies by Major Political Parties" (1999) 1 ELB 3-11.

143 The coalition is supported by the Green Party on matters of confidence and supply.

144 Hon Margaret Wilson "Good Faith Bargaining" (2000) 3 ELB 47.

145 Lorraine Skiffington "Getting the Balance Back into Employment Relations" (2000) 3 ELB 48. 
present under that regime. The writer concurs with the view that the Employment Relations Bill establishes an equilibrium between the Employment Contracts Act and previous employment legislation. ${ }^{146}$

The Employment Relations Bill was passed under urgency following lengthy debate and comes into force on 2 October 2000. While there are changes in the area of personal grievances, ${ }^{147}$ the Employment Relations Act 2000 retains the same definition of a personal grievance as found in previous legislation and therefore the concept of "unjustifiable dismissal" remains both applicable in law, and statutorily undefined. ${ }^{148}$

The introduction of the Employment Relations Act poses a number of interesting, complex and open questions. The new Act makes it clear that the good faith requirements it contains apply to matters of redundancy. ${ }^{149}$ However it is yet to be established whether the general duty of "good faith" under the Employment Relations Act ${ }^{150}$ is synonymous with the common law duty of mutual trust and confidence or whether it goes further in the duties it imposes on employers and employees. ${ }^{151}$

A question of greater relevance to the scope of this paper is whether the Courts will once again perceive that the concept of unjustified dismissal requires reinterpretation to reflect the new context in which it is found. The objects section of the Employment Relations Act emphasises, among other things, the promotion of collective bargaining, good faith behaviour and acknowledges the inherent inequality of bargaining power in employment relationships. ${ }^{152}$ If a reinterpretation of the personal grievance provisions reenacted in the Employment Contracts Act was warranted in recognition of the new context in which they operated, then perhaps it is arguable that their reinterpretation is similarly justified under the Employment Relations Act. My paper questioned the desirability of revisiting this area of the law again. One must also question whether it is

146 Bernard Banks "The Pendulum Swings Part Way Back - the New Employment Law" (2000) 1 ELB 2.

147 The key area of change is a shift in emphasis towards mediation as the primary means of dispute resolution under s 114, and reinstatement as the primary remedy under s 125 of the Employment Relations Act 2000.

148 The Employment Relations Act 2000 s 103 contains what was s 27 of the Employment Contracts Act 1991.

149 Section 4(4)(e) of the Employment Relations Act 2000.

150 Section 4(1) of the Employment Relations Act 2000.

151 See generally Paul Roth "The Individual Employment Relationship under the New Industrial Legislation" (2000) 5 ELB 94, 95.

152 Section 3 of the Employment Relations Act 2000. 
realistic to expect the Courts to accept that the personal grievance provisions require such reinterpretation. 